\title{
The Retention of IT Sales Professionals
}

\author{
David Hemmans ${ }^{1, *}$, Santosh Sambare ${ }^{2}$ \\ ${ }^{1}$ Johnson School of Business, Hodges University, Fort Myers, 33966, US \\ ${ }^{2}$ School of Business, Hesser College, Manchester, 03103, US
}

\begin{abstract}
The IT solutions industry has faced many challenges related to the retention of the sales force. This research evaluated many factors that influence the decisions of IT Solutions sales professionals to continue their employment with their current employer. It identifies the perceptive views of IT sales professionals on the effects of salary and non-salary factors on the voluntary turnover of these sales professionals. As Vice President of software sales at Freightcenter, Inc. and former director of global sales at Microdasys, Inc., the co-author Dr. David Hemmans finds the retention of IT sales professionals to be a growing concern among today's IT solution sales organizations. As Associate Professor in Business Administration and with several years of experience in Marketing, Strategic Planning and Business Analytics, in various industries such as pharmaceutical, telecommunications, consumer products, biotech as well as insurance the co-author Dr. Santosh Sambare sees direct application of the results of this study in addressing the concerns of turnover in the sales professionals not only in the IT industry but also other environments as well. This research concludes that several salary as well as several non-salary factors affect the decisions of IT sales professionals to maintain employment with their current employer. This research indicates that companies need to provide support to their sales professionals by providing good leads, qualifying these leads, emphasizing sales training, having clearly articulated pricing policies, and promoting excellent installation and customer service. This research concludes that job satisfaction is more important than base pay or commissions in influencing the IT sales professional to remain with their employer. The key recommendation to IT solutions companies from this research are that focusing on job satisfaction, recognition, and support services are more important than base pay and bonuses to maximize IT sales professional retention. The implication of the results of this study for IT sales management is to also focus beyond the traditional salary based factors such as base pay, commissions and bonus plans and concentrate on job satisfaction of their IT solutions sales managers. Also, it suggests sales management to show concern and care for their sales professionals and ensure that they have good scope for advancement in their organizations. In addition, sales management should ensure that the sales position is challenging and provide training programs to help sales professionals meet their goals as well as to provide the support needed by the sales professionals to be successful in their positions. Such support includes access to accurate customer data, timely access to internal engineering and pre-sales resources, and assistance from upper management in closing major deals.
\end{abstract}

Keywords Sales Management, Technology Sales, Organizational Development, Retention, Sales Strategy, Sales Leadership

\section{Introduction}

The IT solutions industry provides technology solutions to a wide spectrum of companies worldwide. In the past two decades, this industry has been characterized by a relatively high growth rate and a significant increase in personnel. This has given rise to some of the challenges involved in retaining employees, particularly those in the sales function. Some of these challenges are:

Increases in the number of firms offering IT Solutions

Increases in income and flexible working conditions

Decreases in loyalty of employees

* Corresponding author:

dhemmans@hodges.edu (David Hemmans)

Published online at http://journal.sapub.org/mm

Copyright (C) 2011 Scientific \& Academic Publishing. All Rights Reserved
Difficulties in retaining qualified personnel

Langley (2006) noted that the number of technology professionals will continue to grow worldwide because technology has emerged as an important impetus for business. Companies use information technology to perform a wide range of business functions. Technology is a vital necessity in providing companies with the tools necessary to gain competitive advantages in their respective industries. Pabilonia and Zoghi (2005), attributes the significant increase in the number of professionals entering the technology sector as a result of higher salaries being offered to technology professionals.

\section{Objectives}

Little is known about human resource management practices in the IT solutions industry in spite of the fact that high 
technology organizations are consistently rated as excellent organizations in which to be employed (Buckley et al., 2008). The average starting income of IT sales professionals is one of the highest compared to other professions. In an annual survey, IT professionals experienced an average salary increase of $4.6 \%$ from 2008 to 2009 , and this trend is expected to continue (Ferguson, 2009). IT professionals in the banking and financial services industry saw an average annual salary increase of more than 5\% (Ferguson, 2009). There are challenges in managing the turnover of technology professionals because IT professionals who change jobs generally manage to obtain increases in wages (Morgan, Campione, \& Jerrell, 2004). Based on the current findings, why should IT sales professionals be loyal to their employers? What motivates some IT sales professionals to remain with their current employers while others do not do so? There is a need to understand the factors that motivate IT Sales Professionals to change their current jobs. Hemmans (author) finds voluntary turnover to be an important issue based on his experiences with staff turnover as Vice President of software sales at Freightcenter, Inc. and former director of global sales at Microdasys Inc. Sambare (author) finds importance in voluntary turnover because sales in an important function in any industry and having loyal sales professionals is vital to maintain healthy sales results in any company.

Understanding sales professional motivation would ultimately result in improving retention strategies. IT Solutions companies also offer relatively flexible working conditions. According to the Chartered Institute of Personnel and Development, two-thirds of technical employees have seen an average of $20 \%$ increase in flexible working conditions over the past few years, as a result of efforts by organizations to improve workplace practices (Samuels, 2005). Companies have hoped that increases in income and flexible conditions would result in increased loyalty but unfortunately this has not happened. Major hardware and software companies fear a decrease in loyalty among IT professionals because of the steadily increasing salaries for college graduates with computer science and engineering degrees (Samuels, 2005). It is important to evaluate if other factors also play a part in IT professional retention and if so, how significant of a part do they play. Competition has increased in the IT solutions industry with more job opportunities which has contributed to challenges in finding qualified employees and retaining them. In February 2008, voluntary turnover accounted for more than $56 \%$ of total separations in the US and this number is expected to grow in the professional and business industries (Bureau of Labor Statistics, 2008).

\subsection{Retention}

The question that today's IT solution sales companies face is how to design a retention strategy to produce desired outcomes. Monetary factors may not be the optimal method to deter IT sales professionals from changing companies. Many of today's companies are looking at alternate ways to motivate their IT staff to maximize talent retention. This research will seek to determine if monetary compensation such as sales plans and commissions structures play a greater role in the voluntary turnover of IT sales professions than non-compensation factors.

\subsection{Retention of IT Sales Professionals}

Retention is a major concern in the IT solutions industry because companies are focused on lowering hiring and training costs. The sales group is an extremely important department for IT solutions companies. IT sales professionals are responsible not only for selling and promoting the company's products and services but are the key source for obtaining strategic, marketing and competitive information. They identify customer needs and assess competitive impact, while developing trust and confidence in their customers. The time, costs, and effort put into recruiting talented IT sales executives force sales managers to understand the issues that are important to maximize sales performance (Sanjay, 2009). They are representatives and ambassadors to customers and serve the dual function of generating sales volume and acting as the "marketing" eyes and ears of the organization. IT sales professionals are very important in the short and the long term. It is therefore a considerable loss when an IT sales professional leaves the company.

\subsection{Sales Force Compensation}

In most IT solutions organizations, sales force compensation typically consists of a combination of salary, commissions, bonuses, stocks, stock options, etc. This compensation plays an important role in motivating sales professionals and is traditionally regarded as one of the driving forces to acquire the loyalty of sales professionals. Compensation is one of the factors that drive the motivation of IT sales professionals to sell products and services as well as obtaining information and strategic inputs from customers and prospects. IT sales professionals need to have excellent selling skills as well as sound knowledge of technology products and services. Many companies mainly concentrate on compensation factors when developing retention strategies for their respective sales group. Concentrating only on monetary benefits can lead to missing opportunities to adequately motivate the sales force so that they can be driven to sell the products and services.

An important question that each sales manager should ask is to what extent the compensation program is powerful enough to achieve the optimum motivational impact and result in improving retention. Is it worthwhile to spend dollars on compensation packages or are there any other factors that influence sales force motivation? In addition, sales professionals need to trust the company they work. IT sales professionals need to feel confident that their company will provide them the products and services customers need and value as well as the necessary to tools to effectively sell the products and services. Sales professionals also need recognition. Some companies recognize sales professionals' desire to be recognized but others do not. Some of the key things 
the sales manager should remember:

Develop a sense of trust among his or her sales team

Provide timely recognition to successful sales professionals

Provide them tools to be successful in their business

\subsection{Retention Strategies}

Organizations that place higher priority on retention strategies are experiencing significantly lower levels of voluntary turnover (Tae et al., 2008). In most industries the retention of sales professionals is an issue because sales professions have traditionally experienced high turnover. This turnover tends to be related to the length of employment. In 2008 , organizations faced a $16 \%$ voluntary attrition rate for employees with fewer than five years of experience (Hedden \& Anselmo, 2008).

A sound retention strategy will have a profound effect on retaining IT sales professionals because it will increase their productivity and performance. This is extremely important because of its direct effect on the customers. Sales professionals over time develop relationships with their customers and these relationships are key drivers for customer loyalty. These loyal customers will continue to give their business to the company. Many a times when sales professionals leave the company they take their customers with them. IT solutions companies at times may only have a few key customers and so losing some of these customers could have a direct impact on the business. Retaining sales professionals is an important element for effective leadership. IT solution sales organizations must possess the knowledge and understanding of the behavior of IT sales professionals and incorporate these factors in the retention strategies. It could be argued that sales is the most important function of any organization. Sales professionals are important and the attitudes and work behaviors of these professionals are directly impacted by the perceptions of leadership (Barbour, 2007). Organizational performance can be maximized by creating a culture that is aligned with social and cultural values of employees (Brandt, 2004). The reduction of voluntary IT sales professional turnover can improve efficiency by reducing the costs associated with retaining IT sales professional talent. It costs about six times more to train a new IT sales professional as opposed to retaining existing IT sales professionals.

Based on the fact that the selection of IT professionals is very challenging, the Six Sigma process can be used to reduce the time of selecting sales personnel (Sutton, 2006). General Electric reported a savings of \$2 billion in 1999 attributable to six sigma, and a 2001 annual report revealed that the company yielded over $\$ 3$ billion in savings (Hayes, 2009). Human resource departments can apply Six Sigma techniques to analyze the quality of IT sales professional performance to those of new and replacement professionals during the hiring process. In the 1980s, Six Sigma resulted in the reduction in General Electric's workforce from 400,000 to 300,000 while increasing net profit from $\$ 3$ billion to $\$ 4$ billion (Sutton, 2006).

\subsection{Research Study}

The purpose of this research study is to identify and quantify the monetary and non-monetary factors that are related to the voluntary turnover of IT sales professionals. A quantitative study was used to focus on the decisions that IT sales professionals make in voluntarily choosing to leave one IT sales organization to work for another IT sales organization. This research study can be used to identify the key factors that IT solutions companies must consider in formulating effective retention to reduce voluntary turnover. This research examines why some IT sales professionals stay with the same organization while others change companies. High staff loyalty is related to the loyalty of customers (Griffin, 2003).

It is imperative to identify factors that are important to IT sales professionals and then incorporate these factors in the retention plan. Various factors can affect the decision of IT sales professionals to stay with their current organization. These can be divided into salary based and non-salary based factors. This research study analyzed the relation between the non-salary based strategies that attract and retain talented IT sales professionals and minimizes IT sales professional attrition. Personal and organizational factors can affect these decisions that must be addressed on a case-by-case basis (Moderi \& Foote, 2005).

In this research study salary and non-salary based factors are evaluated in terms of their influence on IT sales professionals to be loyal to their current organizations. The independent variables for the present study are:

1. Salary based factors such as base pay, bonuses, commissions and salary increases.

2. Non-salary factors which include relationship with the sales manager, training, career advancement, job satisfaction, job fulfillment, sense of ownership, and satisfaction in helping customers.

This study focuses on the determinants of IT sales professional retention based on the viewpoints of IT sales professionals and sales managers in a variety of IT sales environments. Various factors can affect the decision of IT sales professionals to stay with their current organization. These can be divided into salary based and non-salary based factors. IT sales professionals in the IT solutions industry are highly paid but monetary benefits are not the only factors that influence the decision of IT sales professionals to stay with their respective organization. This research study analyzed the correlation between the non-salary based strategies that attract and retain talented IT sales professionals and minimize IT sales professional attrition. The independent variables for the study were the salary based factors such as base pay, bonuses, commissions and the non-salary factors which are relationship with manager, training, career advancement, job satisfaction, job fulfillment, sense of ownership, and satisfaction in helping customers. It also develops a metric to measure the degree of relationship of each independent variable on the dependent variable in this research study which is sales force retention. Creating a plan that addresses 
all the independent variables in the present study may prove to be the optimal method of improving IT retention. This research study established a metric for measuring the effects each independent variable has on IT sales professional retention. Various independent factors used in this study are discussed below.

\subsection{Base Pay}

IT sales professionals are among the highest paid individuals in today's business environment. In the IT solutions industry, pay raises have continued to outpace inflation, and average bonuses exceed 11\% (Schultz, 2007). Offering competitive salaries to minimize turnover based on normative commitment can be an inefficient retention strategy. This is because the salary factors may not be related to guarantee continuance of commitment on the part of these IT sales professionals (Addae, Parboteeah, \& Velinor, 2008). Schultz (2006) points out that despite pay advantages, IT sales professionals are not satisfied with salary to motivate them to stay with their current organizations. This forces IT solution sales organizations to not only offer competitive salaries, but to find other incentives to maximize retention. Each IT sales professional could have different viewpoint and interpretations about their salary and this gives rise to multiple viewpoints about the importance of their base pay. All perspectives need to be investigated to come up with the sound interpretation of salary by IT Sales Professionals. This study has focused on doing that.

\subsection{Relationship with Manager}

While salary continues to be perceived as the number one factor in recruiting and retaining IT sales professionals, the relationship with manager plays a vital role in influencing the comfort level of IT sales professionals in their current position. Sales managers can provide an environment that adds professionalism and trust while promoting comfort and cohesiveness for IT sales professionals in his or her team. Creative work incentives such as telecommuting and flexible hours are factors that are helping organizations acquire and keep top talent (Hoffman, 2008). Job flexibility can improve the retention rate and can have a positive relationship with the overall profitability of an organization. The sales cycle of IT solutions can cover a wide time horizon and this means that IT sales professionals need to have excellent project management and relationship building skills to promote customer satisfaction and loyalty. Innovative retention strategies such as job sharing, telecommuting, and flexible work rules can improve retention of IT sales professionals (Ko \& Osei-Bryson, 2008). Frequent internal communication between managers and employees allow the opportunity to solve issues that threaten an employee's success (Allen, 2007).

\subsection{Training}

Although researchers have established a relationship between human resources management practices and organ- izational performance, the intervening process connecting human resource management (HRM) system, training, and organizational performance have not had much exploration (Geare, Edgar, \& McAndrew, 2006). The existence of training and career development programs can promote retention by providing IT sales professionals with a sense of purpose and usefulness to IT solution sales organizations. A key influencer in the retention of IT professionals is the existence of a healthy and consistent career development environment (Brooker, 2008). According to Lee-Kelley, Blackman, and Hurst (2007), a positive relationship exists between the promotion of learning disciplines and the reduction of employment turnover. Investing in the improvement of training programs can significantly decrease employee voluntary turnover.

\subsection{Career Advancement}

The support and encouragement of the organization can play a key role in motivating IT sales professionals which can improve retention. The perceptions employees have on how their respective employer values career development and advancement can relate to how comfortable employees feel about working for an organization. Career development programs give employees the opportunity to have a sense of professional identity (Cross, Hicks, Parle, \& Field, 2006). Today's IT sales professionals look for career advancement and growth paths that can lead to upper management as well as additional responsibilities coupled with salary increases. Career development and advancement programs can promote loyalty among IT sales professionals. These programs can also provide IT sales professionals with networking skills to maximize career growth. Having good relations with the right network of individuals within an organization is important to maximizing career advancement (Day, 2007). Career development programs improve the productivity and performance of IT employees, encourage loyalty, and improve the relationship between employees and employers (Cross et al., 2006). Career development programs can consist of periodic (annual or semi-annual) discussions with IT sales executives on career goals and objectives along with establishing action plan for the successful achievement of the career goals.

\subsection{Job Satisfaction}

Job satisfaction can play an intricate part in helping IT sales professionals gain a sense of commitment to an organization. Focusing on innovative ways to promote job satisfaction can be an optimal method of increasing retention in the IT profession. Job satisfaction is a measurement that is widely used to view employee's attitudes of overall acceptance, enjoyment, and in their work (Lee-Kelley, Blackman, \& Hurst, 2007). Job satisfaction could provide a competitive advantage which can have a positive impact on the decisions IT sales professional to remain employed with their current employer rather than except a higher salary offer from another organization. 


\subsection{Job Fulfillment}

Job fulfillment can have a positive influence on the retention of IT sales professionals. Sustained longer-term employment can result from job fulfillment because job fulfillment is intrinsically connected to professional success (Feyerherm \& Vick, 2005). IT sales professionals can have a major interest in having a role that is fulfilling as well as rewarding. Job fulfillment can improve the rate of retention and reduce retention costs (Sudheimer, 2009). Evaluating the level that IT sales professionals perceive their job as being fulfilling can be an optimal methodology in determining how to reduce retention.

\subsection{Sense of Ownership}

Instilling a sense of ownership of an organization can have a profound effect on the retention of IT sales professionals. According to van Dyne and Pierce (2004), employees that have a sense of psychological ownership with their respective organizations perform significantly better than employees that do not have a sense of ownerships. Personal ownership of career and collective accountability from the organization and the employee are key contributors in boosting retention (Yost, 2006). IT sales professionals can share the same social values as the organization which could have a positive relationship with loyalty and commitment to the organization.

\subsection{Satisfaction in Helping Customers}

IT sales professionals have a desire to help customers. This desire to help customers coupled with having an intrinsic drive to learn technology can be of key motivational value to IT sales professionals. IT sales professionals that have a high desire to learn technology and enjoy helping customers can help organizations increase customer retention and loyalty. This is in turn has a positive impact on the loyalty of IT sales professionals. Satisfied employees benefit the organization by exhibiting various desired behaviors, including helping others and various forms of organizational citizenship behavior (Bradford, Crant, \& Phillips, 2006). The mindset of today's businesses must be to constantly strive to evolve into a better organization (Puffer, 2004). IT organizations must focus on improving the retention of IT sales professionals in the US because the boomer generation retirement range began in 2010, leaving Generation Y employees to fill their roles (Rexroad \& Shoffner, 2003). Being prepared for evolution gives an organization the ability to respond to threats effectively.

\subsection{Research Design}

This research study gathered the perspective views of IT retention from IT sales professionals. This research design is quantitative in nature. The purpose of this study is to identify and quantify the monetary and non-monetary factors that are related to the voluntary turnover of IT sales professionals. This study attempted to understand why IT sales professionals make decisions to change employers.
This research study addressed how IT sales personnel tradeoff between the monetary rewards versus non-monetary rewards from their jobs. It investigates the IT sales profession and how it has evolved over the last two decades. Based on the competitive salaries offered and the increased in demand, more individuals are turning to the technology industry for employment (Allen, 2007). Retention themes and patterns which emerge from the examination of organizational culture are from the foundation of individual leadership styles. Each situation may demand a different approach which is dictated by the sum of the skills comprised by the respective organization's management team.

In order to have effective leadership, IT solution sales organizations must possess knowledge and understanding of the behavior and the motivation of the IT sales professionals. The attitudes and work behaviors of professionals are directly impacted by the perceptions of leadership (Barbour, 2007). The perceptions of leadership style by IT sales professionals can have a positive relationship with the organizational performance. Creating an organizational culture that has an alignment of desired organization values and social values of employees is the optimal environment for maximizing organizational performance (Brandt, 2004). The examination of the needs of the IT solution sales personnel can allow IT solution sales organizations to improve the retention of talent. This research examined the organizational culture of IT solution sales organizations to determine how to improve IT sales professional turnover.

\subsection{Research Method and Design}

The Research Design for this study includes:

Methodology

Questionnaire design and testing.

Sample selection

\section{Methods}

This research study used a quantitative method to measure the dependent and independent variables examined by this research study. Quantitative methodology was appropriate in this type of study because it focuses on the understanding of a variety of relationships between independent and dependent variables and does not attempt to control an environment as opposed to qualitative studies. Draper (2004) attributes quantitative studies as being better equipped to handle the complexities involved in measuring human behavior. Qualitative research can cause substantive and disciplinary problems because of the fallacy of control perceived by researchers (Prakash \& Klotz, 2007). Quantitative methodology was appropriate for this study because the focus of this research was to obtain an understanding of the relationship between the dependent and independent variables. This research helped to develop a measure of association between variables as well as to evaluate the importance of salary and non-salary variables on retention of IT Sales Professionals. 
This research study consisted of a sample size of 116 IT sales professionals and sales managers from large and medium-size IT solution sales organizations. A questionnaire was specifically developed for this study and it was validated using a small sample of respondents. This questionnaire was used to obtain the relevant data and to analyze the effects of the independent variables (salary and non-salary factors) on the dependent variable (retention) of this research study. The effect of each independent variable was examined to determine whether salary or non-salary factors play the greater role in the retention of IT sales professionals. The findings of this research study could improve retention strategies by helping IT solutions sales organizations understand the behaviors that have a positive impact on employee motivation and loyalty. For the purpose of this research study, productivity and sales performance referred to the contribution of the individual sales revenue generated by each IT sales professionals within a certain time.

\subsection{Questionnaire Design and Testing}

A survey instrument was developed and pre-tested in a pilot study with two IT sales managers and three IT sales professionals to ensure reliability and validity of the survey instrument to obtain the data needed for the study. This pretesting ensured the proper interpretation of the questions by IT sales professionals. Respondents were asked the importance of various factors that are related to their decision to remain with their company. The factors were, whether the job was fulfilling, challenging, had good pay, had a good bonus plan, had opportunities for advancement, had good training programs, promoted satisfaction in helping customers, promoted ownership of solutions provided to customers, and promoted satisfaction in providing solutions to customers. The survey included Likert scale questions designed to elicit responses from participants on views and attitudes on issues that relate to IT sales retention.

Table 1. Sample Size Estimates

\begin{tabular}{|c|c|c|}
\hline & $\begin{array}{c}\text { Sales force } \\
\text { attrition } 15 \%\end{array}$ & $\begin{array}{c}\text { Sales force } \\
\text { attrition } 20 \%\end{array}$ \\
\hline Variance & .13 & .16 \\
\hline Estimated Standard Deviation & .36 & .40 \\
\hline Precision & $7 \%$ & $7 \%$ \\
\hline Square Root of Sample Size & 9.96 & 11.20 \\
\hline Sample Size & 99 & 125 \\
\hline
\end{tabular}

\subsection{Sample}

After pretesting, the survey instrument was sent via email to five IT sales executives and ten IT sales managers. Each IT sales professional was requested to complete the survey and distribute survey to seven IT sales professionals and eight IT sales managers. Each IT sales manager was requested to complete the survey and distribute the survey to eight IT sales professionals and seven IT sales managers. The research study yielded 116 usable responses consistingof 51 IT sales managers and 65 IT sales professionals. The population of sales managers included 38 males and $13 \mathrm{fe}$ - males while the population of IT sales professionals included 36 males and 30 females. The population for this research study was IT sales professionals and IT sales managers from medium and large-size IT organizations. Table 1 analyses the population to determine an accurate sample size.

This research study used an attrition rate of $15 \%$ to $20 \%$ which was based on an estimation of projected attrition in the Infosys industry by Shivashankar and Kannan (2007). Also, the national average retention rate in the US is between 15 and $20 \%$ according to the Bureau of Labor Statistics (2009). Based on these assumptions, the required sample size was estimated at 110 .

\section{Results}

The purpose of collecting the data was to answer the following research question:

What plays the greatest role in IT sales professional retention salary related factors or non-salary factors?

The data collected from the survey instrument were used to determine the relationship between retention of IT sales professionals and salary versus non-salary variables. These non-salary variables included factors such as relationship with the manager, training given to the sales professional by the company, career advancement, job satisfaction, job fulfillment etc. This quantitative study evaluated the perceptions of IT sales professionals and IT sales managers on factors that are related to decisions made by IT sales professionals to remain employed with their current employer.

\subsection{Characteristics of Respondents}

The survey participants consisted of IT sales professionals and sales managers in medium and large-size IT solution sales organizations. The medium-size IT organizations consisted of companies with annual sales revenues between $\$ 100$ million and $\$ 1$ billion while large-size IT organizations consisted of companies that had annual sales revenues greater than $\$ 1$ billion. The large-size companies targeted by this research study were companies such as IBM Corporation and Dell Inc., and the medium-size companies targeted by this research study were technology resellers such as IBM and Dell business partner companies. The respondents requested not to be identified to avoid conflict of interest with the organizations represented.

The survey sample consisted of approximate $63 \%$ male and $37 \%$ female respondents The age group represented in the sample included about $19 \%$ of the respondents between 20-30 years old, approximately $38 \%$ of the respondents that were $31-40$ years old, about $24 \%$ of the respondents that were $41-50$ years old, approximately $19 \%$ of the respondents that were between 51-60 years and approximately $2 \%$ of the respondents that were more than 60 years old. The median professional age of white-collar workers in the US was 37.1 (Demographics Now, 2009), which falls under the median age group of the sample of this research study which falls 
between 31-40years.

This sample also varied in terms of their education level with $67 \%$ of respondents having a bachelor degree, $30 \%$ individuals in this sample with a master degree and 3\% having a doctorate degree. According to the US average, professionals with bachelor degrees are almost double the number of professionals with master's degrees (Demographics Now, 2009). This makes the sample in this research to some extent comparable with the US population. The ratio of Masters to Bachelors degrees is close to 2:1 as noted in the US population. The length of employment for respondent in the survey sample consisted of approximately $52 \%$ of the participants employed with his or her respective employer for 1-5 years, approximately $27 \%$ of the participants employed with his or her respective employer for 6-10 years, $9 \%$ of the participants employed with his or her respective employer for $11-15$ years, $7 \%$ of the participants employed with his or her respective employer for $16-20$ years, $2 \%$ of the participants employed with his or her respective employer for 21-25 years, and 3\% of the participants employed with his or her respective employer for more than 25 years.

\subsection{Importance of Various Factors in Their Decisions to Change Positions}

In the survey respondents were asked to indicate the importance of various factors in their decisions to change their positions. These mean rating, on a 10 point scale, for responses to these questions are given in Table 2:

It can be inferred from the results in Table 2 that the three most important variables that influence IT sales professionals decisions not change their current employment are:

1. Sense of ownership of the solutions that they provide to their customers

2. Satisfaction in providing solutions to customers

3. atisfaction in helping customers

Table 2. Importance of Various Factors in sales professional's decisions to change positions

$\begin{array}{cc}\text { Variables } & \text { Mean Rating } \\ \text { I get a sense of ownership of the solutions I provide to } & 8.24 \\ \text { customers } & 8.19 \\ \text { I get satisfaction in providing solutions to customers } & 8.09 \\ \text { I get satisfaction in helping customers } & 7.80 \\ \text { Extremely good base pay } & 7.36 \\ \text { Good bonus plan } & 7.25 \\ \text { Good raises every year } & 7.18 \\ \text { Good scope for advancement } & 7.09 \\ \text { My manager cares about my career } & 6.46 \\ \text { The job is very fulfilling } & 6.36 \\ \text { Company has good training programs } & 6.06 \\ \text { Position is very challenging } & \end{array}$

These results have important implication for sales management and leadership in IT Solutions Organizations. These organizations need to provide the required tools to IT sales professionals to enable them to assist their customers. These results indicate that the higher the sense of ownership of the solutions provided to customers the more the likelihood of IT sales professionals not to change their position. These IT sales professionals get pride and satisfaction in providing solutions to their customers and derive satisfaction in helping their customers. The higher this satisfaction the greater is the chance that the IT sales professionals will continue with their current employer. This underscores the need for IT Solutions Organizations to provide support for their sales professionals.

\subsection{Sales Support Provided by Company}

Respondents were asked about the sales support provided by their company on various factors. These responses were obtained on a 4 point scale which included:

1. No Support

2. Low Support

3. Medium Support

4. High Support

These results are shown in Table 3 below. It appears from these results that generally low to medium support was provided by the companies to IT sales professionals on most of these factors.

Table 3. Level of Sales Support Provided by the Company

$\begin{array}{cc}\text { Variables } & \text { Mean Rating } \\ \text { I am provided good leads for my sales calls } & 2.7 \\ \text { I get pre sales support in terms of qualification of } & 2.7 \\ \text { leads } & \\ \begin{array}{c}\text { I have engineering and design services conducted to } \\ \text { prepare my proposal }\end{array} & 3.5 \\ \begin{array}{c}\text { The proposals are reviewed for by internal support } \\ \text { staff in the timely fashion }\end{array} & 3.5 \\ \begin{array}{c}\text { The company provides clear information on pricing } \\ \text { policies }\end{array} & 3.3 \\ \text { It is easy to come up with the price for the customer } & 3.8 \\ \text { Post-sales installation service is good } & 3.8 \\ \text { Customer questions are answered by customer } \\ \text { service personnel }\end{array}$

Table 3 presents the levels of support by the company to IT sales professionals. The percentage rating for these variables for various levels of support is shown in this table. Examining the data in this fashion provides additional insights in to the perception regarding the support provided by their company, it can be inferred from these results that providing sales professionals with tools to help them estimate a price for their customers is helpful to increase their likelihood to stay with their employer. By the same token post installation service as well having good customer service to answer questions could have the same effect which is presented below in Table 4:

These responses show that companies offered low to medium level of support to IT sales professionals in most cases. Companies provide support but not at a high level as required by IT sales professionals to perform their jobs, Only in a handful of cases the support is good such as in providing engineering and design services as well as reviewing proposals in a timely manner. These results have significant implication for managing and motivating IT sales professionals. There is a clear need to improve the support pro- 
vided to IT sales professionals in most support factors included in this research. This is a major implication for the IT Solutions Organizations; they need to provide good leads, training, have clearly articulated pricing policies, excellent installation and customer service. This could go a long way to retain IT Solutions Sales Professionals.

Table 4. Rating for Support Variables Provided by the Company to Sales Professionals

\begin{tabular}{|c|c|c|c|c|}
\hline & $\begin{array}{l}\text { No Sup- } \\
\text { port }\end{array}$ & $\begin{array}{c}\text { Low } \\
\text { Support }\end{array}$ & $\begin{array}{l}\text { Medium } \\
\text { Support }\end{array}$ & $\begin{array}{c}\text { High } \\
\text { Support }\end{array}$ \\
\hline $\begin{array}{l}\text { I am provided } \\
\text { good leads for my } \\
\text { sales calls }\end{array}$ & $0 \%$ & $44 \%$ & $39 \%$ & $17 \%$ \\
\hline $\begin{array}{c}\text { I get pre sales } \\
\text { support in terms } \\
\text { of qualification of } \\
\text { leads }\end{array}$ & $0 \%$ & $44 \%$ & $39 \%$ & $17 \%$ \\
\hline $\begin{array}{l}\text { I have engineer- } \\
\text { ing and design } \\
\text { services con- } \\
\text { ducted to prepare } \\
\text { my proposal }\end{array}$ & $0 \%$ & $0 \%$ & $51 \%$ & $49 \%$ \\
\hline $\begin{array}{l}\text { The proposals are } \\
\text { reviewed for by } \\
\text { internal support } \\
\text { staff in the timely } \\
\text { fashion }\end{array}$ & $0 \%$ & $0 \%$ & $51 \%$ & $49 \%$ \\
\hline $\begin{array}{l}\text { The company } \\
\text { provides clear } \\
\text { information on } \\
\text { pricing policies }\end{array}$ & $0 \%$ & $0 \%$ & $67 \%$ & $33 \%$ \\
\hline $\begin{array}{l}\text { It is easy to come } \\
\text { up with the price } \\
\text { for the customer }\end{array}$ & $0 \%$ & $33 \%$ & $59 \%$ & $9 \%$ \\
\hline $\begin{array}{l}\text { Post-sales instal- } \\
\text { lation service is } \\
\text { good }\end{array}$ & $0 \%$ & $29 \%$ & $62 \%$ & $9 \%$ \\
\hline $\begin{array}{l}\text { Customer ques- } \\
\text { tions are an- } \\
\text { swered by cus- } \\
\text { tomer service } \\
\text { personnel }\end{array}$ & $0 \%$ & $29 \%$ & $62 \%$ & $9 \%$ \\
\hline
\end{tabular}

Table 5. Correlations Between Types of Support and Likelihood of Sales Professionals to Change Companies

\begin{tabular}{|c|c|c|c|c|}
\hline & Leads & $\begin{array}{l}\text { Qualifying } \\
\text { Leads }\end{array}$ & Engineering & Timely \\
\hline 6 months & $0.23 *$ & $0.23^{*}$ & $-0.63^{*}$ & $-0.63^{*}$ \\
\hline 12 months & $0.61 *$ & $0.61 *$ & $-0.43 *$ & $-0.43 *$ \\
\hline 18 months & $0.92 *$ & $0.92 *$ & $-0.71 *$ & $-0.71 *$ \\
\hline 24months & $0.87 *$ & $0.87 *$ & $-0.77 *$ & $-0.77 *$ \\
\hline 3years & $0.86^{*}$ & $0.86^{*}$ & $-0.78 *$ & $-0.78^{*}$ \\
\hline 4 years & $0.81 *$ & $0.81^{*}$ & $-0.83 *$ & $-0.83 *$ \\
\hline 5 years & $0.83 *$ & $0.83^{*}$ & $-0.79 *$ & $-0.79 *$ \\
\hline 6 years & $0.84^{*}$ & $0.84 *$ & $-0.83^{*}$ & $-0.83^{*}$ \\
\hline & $\begin{array}{l}\text { Pricing } \\
\text { Policies }\end{array}$ & $\begin{array}{l}\text { Price for } \\
\text { Customer }\end{array}$ & Installation & $\begin{array}{c}\text { Customer } \\
\text { Service }\end{array}$ \\
\hline 6 months & $-0.45^{*}$ & $-0.82 *$ & $-0.88^{*}$ & $-0.88^{*}$ \\
\hline 12 months & $-0.15 *$ & 0.02 & -0.03 & -0.03 \\
\hline 18 months & $-0.37 *$ & $-0.09 *$ & -0.16 & -0.16 \\
\hline 24 months & $-0.43^{*}$ & $-0.26^{*}$ & $-0.33 *$ & $-0.33 *$ \\
\hline 3 years & $-0.45^{*}$ & $-0.28 *$ & $-0.35^{*}$ & $-0.35^{*}$ \\
\hline 4 years & $-0.41 *$ & $-0.31 *$ & $-0.39 *$ & $-0.39 *$ \\
\hline 5 years & $-0.50 *$ & $-0.30 *$ & $-0.38 *$ & $-0.38^{*}$ \\
\hline 6 years & $-0.43^{*}$ & $-0.29^{*}$ & $-0.36^{*}$ & $-0.36^{*}$ \\
\hline$*=p<.05$ & & & & \\
\hline & \multicolumn{4}{|c|}{$\begin{array}{c}\text { Abbreviations for variables used in the } \\
\text { analysis }\end{array}$} \\
\hline Leads & \multicolumn{4}{|c|}{ I am provided good leads for my sales calls } \\
\hline
\end{tabular}

\begin{tabular}{|c|c|}
\hline Qualifying Leads & $\begin{array}{l}\text { I get pre sales support in terms of qualification of } \\
\text { leads }\end{array}$ \\
\hline Engineering & $\begin{array}{l}\text { I have engineering and design services con- } \\
\text { ducted to prepare my proposal }\end{array}$ \\
\hline Timely & $\begin{array}{l}\text { The proposals are reviewed for by internal } \\
\text { support staff in timely fashion }\end{array}$ \\
\hline Pricing Policies & $\begin{array}{c}\text { The company provides clear information on } \\
\text { pricing policies }\end{array}$ \\
\hline Price for Customer & $\begin{array}{l}\text { It is easy to come up with the price for the } \\
\text { customer }\end{array}$ \\
\hline Installation & Post-sales installation service is good \\
\hline Customer Service & $\begin{array}{l}\text { Customer questions are answered by customer } \\
\text { service personnel }\end{array}$ \\
\hline
\end{tabular}

In order to determine the impact of the level of support provided by the company on retention of IT sales professionals, correlations were run between the support variables and the likelihood of sales professionals to change their positions at different time periods such as within 6 months, 12 months, and 18 months. These results are shown in Table 5.

Correlations between the likelihood to change positions in the next six months were negative for all support factors except for providing leads and qualifying leads. It can be inferred from these correlations that if sales professionals perceive that good support and customer services are offered by their company, there is less likelihood of them changing position within the next 6 to 12 months. These results also indicate that in general there was less likelihood for sales professionals to change their positions in later time periods if they perceive they get good support from their company. All correlations were significant at .05 confidence level except in a few instances such 12 months at price for customer, installation, and questions, and 18 months at installation services and questions answered by customer service personnel. It is important to note from these results that the factors that are important to these sales professionals because of the nature of the product and systems marketed in this industry by the IT Solutions Organizations. These products and systems need high level of planning, engineering, installation and post installation services.

Table 6. Effectiveness of Company Support

$\begin{array}{cc} & \text { Mean Rating } \\ \text { Providing Post-Sales Support. } & 7.18 \\ \text { Professional Sales Management Supervision } & 7.12 \\ \text { Providing useful reporting tools } & 6.87 \\ \text { Providing Presales Support } & 6.75 \\ \text { Providing useful training } & 6.65 \\ \text { Providing useful software tools } & 6.64 \\ \text { Providing good sales support materials } & 6.04 \\ \text { Qualifying leads } & 5.46 \\ \text { Providing leads } & 3.75\end{array}$

\subsection{Effectiveness of Support Provided by the Company}

Respondents were asked about their opinion regarding the effectiveness of the company with respect to several variables such as providing qualified leads, providing pre and post-sales support, having good sales materials and tools 
available to sales professionals, etc. These ratings were obtained on a scale of 1 to 10 , where " 1 " meant not at all effective and "10" means very effective. These results are shown in Table 6.

These results show that sales professionals perceive that their companies provide good sales support and management supervision. These sales professionals are also of the opinion that on the average their companies lack in providing qualifying leads or providing adequate number of leads. The implication of this is extremely important. Sales professionals look to their managers to provide them leads which are qualified. Sales Management can employ resources especially from the marketing and analytics department to obtain and qualify leads. This saves considerable amount of time and effort on part of the sales professional. These correlations are positive and the reasons for this could be that sales professionals do not perceive good support from their organizations in terms of lead generation and so these factors may not play an important role in their likelihood to change positions.

\subsection{Relative Importance of Various Factors Affecting Sales Professionals' Decisions to Change Companies}

In this section various factors were compared in pairs of two to determine the relative importance of these factors in influencing the sales professional to change his or her position.

\section{Comparison of Base Pay versus Job Satisfaction}

A comparison of different variables in influencing sales professionals to stay with their firm is presented in the following tables. These comparisons were accomplished using Analysis of Variance to test for differences in these means. Table 7 shows the comparison between base pay and satisfaction with the job:

As shown in Table 7, the mean rating for base pay in the sales professionals' decision to stay with their respective employer is 7.80 while the mean rating for satisfaction with the job is 9.07. In the analysis of variance shows the F- statistic is 30.04 which is significant at the .05 confidence level. One of the inferences that can be drawn from these statistics is that satisfaction with their jobs is more of driving force for sales professionals' decision to stay with the firm as opposed to their base pay.

Table 7. Analysis of Variance: Base Pay versus Job Satisfaction Summary

\begin{tabular}{cccccc}
\hline Groups & Count & Sum & Average & Variance \\
\hline Base Pay & 116 & 905 & 7.80 & 6.21 \\
Satisfaction & 116 & 1053 & 9.08 & 0.07 \\
\hline \multicolumn{6}{c}{ Anova } \\
\hline $\begin{array}{c}\text { Source of } \\
\text { Variation }\end{array}$ & $\boldsymbol{S S}$ & $\boldsymbol{D f}$ & $\boldsymbol{M S}$ & $\boldsymbol{F}$ & $\boldsymbol{P}$-value \\
\hline $\begin{array}{c}\text { Between } \\
\text { Groups }\end{array}$ & 94.41 & 1 & 94.41 & 30.04 & $1.10647 \mathrm{E}-07$ \\
$\begin{array}{c}\text { Within Groups } \\
\text { Total }\end{array}$ & 722.74 & 230 & 3.14 & & \\
\hline & 817.15 & 231 & & &
\end{tabular}

\section{Comparison of Bonus Plan versus Job Satisfaction}

The importance of bonus plan was compared with job satisfaction in its impact on the likelihood of sales professionals to stay with their current employer. Here again Analysis of Variance was used to test for these differences. These results are shown in Table 8.

Table 8. Analysis of Variance: Bonus Plan versus Job Satisfaction Summary

\begin{tabular}{lccccc}
\hline \multicolumn{1}{c}{ Groups } & Count & Sum & Average & Variance \\
\hline Bonus Plan & 116 & 854 & 7.36 & 8.95 \\
Satisfaction & 116 & 1053 & 9.08 & 0.07 \\
\hline \multicolumn{5}{c}{ Anova } \\
\hline $\begin{array}{l}\text { Source of } \\
\text { Variation }\end{array}$ & SS & DF & MS & $\boldsymbol{F}$ & P-value \\
\hline $\begin{array}{l}\text { Between } \\
\text { Groups }\end{array}$ & 170.69 & 1 & 170.69 & 37.85 & $3.35 \mathrm{E}-09$ \\
$\begin{array}{l}\text { Within } \\
\text { Groups }\end{array}$ & 1037.10 & 230 & 4.50 & & \\
Total & 1207.79 & 231 & & & \\
\hline
\end{tabular}

Table 8 shows that sales professionals rated bonus plan at a mean rating of 7.36 while satisfaction was 9.08 . These means were then compared using an analysis of variance. These results show that the $\mathrm{F}$ value for this comparison is 37.85 which is significant at the .05 level of confidence. These results indicate that job satisfaction had a stronger effect on sales professionals' decisions to stay with current employer as opposed to bonus plan.

\section{Comparison of Bonus Plan versus Sense of Ownership}

Comparisons were run between the mean ratings for bonus plan versus ownership. Analysis of variance was used to test the comparisons. These results are shown in Table 9:

These results illustrated a closer relationship between ownership rather than base pay in decisions made by IT sales professionals to remain employed with their current employer.

Table 9. Analysis of Variance: Bonus Plan versus Sense of Ownership Summary

\begin{tabular}{cccccc}
\hline \multicolumn{1}{c}{ Groups } & Count & Sum & Average & Variance \\
\hline Bonus Plan & 116 & 854 & 7.36 & 8.94 & \\
Ownership & 116 & 956 & 8.24 & 2.20 & \\
\hline \multicolumn{6}{c}{ Anova } \\
\hline $\begin{array}{l}\text { Source of } \\
\text { Variation }\end{array}$ & SS & DF & MS & $\boldsymbol{F}$ & P-value \\
\hline $\begin{array}{l}\text { Between } \\
\text { Groups }\end{array}$ & 44.84 & 1 & 44.84 & 8.04 & 0.004 \\
$\begin{array}{l}\text { Within } \\
\text { Groups } \\
\text { Total }\end{array}$ & 1282.03 & 230 & 5.57 & & \\
\hline
\end{tabular}

Comparison of Base Pay versus Sense of Ownership

The mean rating for ownership was 8.24 while that for base pay was 7.80 . These means were compared using 
analysis of variance in Table 10.

Table 10. Analysis of Variance: Base Pay versus Sense of Ownership Summary

\begin{tabular}{cccccc}
\hline Groups & Count & Sum & Average & Variance \\
\hline Base Pay & 116 & 905 & 7.80 & 6.21 \\
Ownership & 116 & 956 & 8.24 & 2.20 \\
\hline \multicolumn{6}{c}{ Anova } \\
\hline $\begin{array}{c}\text { Source of } \\
\text { Variation }\end{array}$ & SS & DF & MS & F & P-value \\
\hline $\begin{array}{c}\text { Between } \\
\text { Groups }\end{array}$ & 11.21 & 1 & 11.21 & 2.66 & 0.10 \\
Within Groups & 967.68 & 230 & 4.21 & & \\
Total & 978.89 & 231 & & & \\
\hline
\end{tabular}

The difference between these means was significant at the 0.1 level. These results suggested that ownership had a closer relationship with decisions made by IT sales professionals to remain employed with their organization than bonus plan.

Comparison of Base Pay versus Manager Caring for the Sales Professional

These comparisons are shown in Table 11. This Table illustrates that the mean of base pay is higher than manager cares.

Table 11. Analysis of Variance: Base Pay versus Manager Caring for Sales Professional Summary

\begin{tabular}{ccccccc}
\hline Groups & Count & Sum & Average & Variance \\
\hline $\begin{array}{c}\text { Base Pay } \\
\text { Manager } \\
\text { Cares }\end{array}$ & 116 & 905 & 7.80 & 6.20 \\
\hline \multicolumn{7}{c}{ Anova } \\
\hline $\begin{array}{c}\text { Source of } \\
\text { Variation }\end{array}$ & SS & DF & MS & F & P-value \\
\hline $\begin{array}{c}\text { Between } \\
\text { Groups }\end{array}$ & 28.98 & 1 & 28.98 & 4.60 & 0.03 \\
$\begin{array}{c}\text { Within Groups } \\
\text { Total }\end{array}$ & 1450.40 & 230 & 6.31 & & \\
\hline
\end{tabular}

Comparison of Bonus Plan versus Manager Caring for Sales Professional

Comparisons were run between the mean ratings for bonus plan versus manager caring about the sales professional. Analysis of variance was used to test the differences between the ratings for these variables. These results are shown in Table 12:

Table 12. Analysis of Variance: Bonus Plan versus Manager Caring for Sales Professional Summary

\begin{tabular}{|c|c|c|c|c|c|}
\hline Groups & Count & Sum & Average & \multicolumn{2}{|c|}{ Variance } \\
\hline \multicolumn{6}{|l|}{ Manager } \\
\hline Cares & 116 & 823 & 7.09 & \multicolumn{2}{|c|}{6.40} \\
\hline \multicolumn{6}{|l|}{ Bonus } \\
\hline Plan & 116 & 854 & 7.36 & \multicolumn{2}{|c|}{8.95} \\
\hline \multicolumn{6}{|c|}{ Anova } \\
\hline $\begin{array}{l}\text { Source of } \\
\text { Variation }\end{array}$ & $S S$ & $D F$ & $M S$ & $F$ & P-value \\
\hline $\begin{array}{c}\text { Between } \\
\text { Groups }\end{array}$ & 4.14 & 1 & 4.14 & 0.54 & 0.46 \\
\hline $\begin{array}{l}\text { Within } \\
\text { Groups }\end{array}$ & 1764.75 & 230 & 7.67 & & \\
\hline Total & 1768.89 & 231 & & & \\
\hline
\end{tabular}

These results are higher than .05 level of confidence. This indicated a higher impact of bonus plan on the decisions made by IT sales professionals to remain employed by the same employer than manager caring about the sales professional.

\section{Comparison of Training versus Bonus Plan}

Comparisons were run between the mean ratings for bonus plan versus training. Analysis of variance was used to test the comparisons. These results are shown in Table 13:

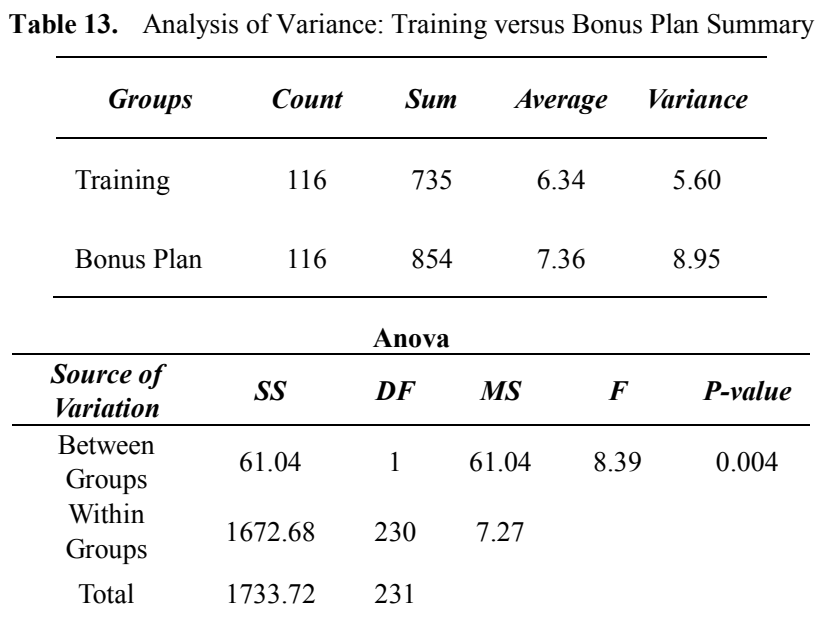

Results from Table 13 indicate bonus plan has a higher mean value in the decision for IT sales professionals to remain employed with the same employer than training.

Table 14. Analysis of Variance: Base Pay versus Training Summary

\begin{tabular}{ccccc}
\hline Groups & Count & Sum & Average & Variance \\
\hline Base Pay & 116 & 905 & 7.80 & 6.21 \\
Training & 116 & 735 & 6.34 & 5.60 \\
\hline
\end{tabular}

\begin{tabular}{cccccc}
\hline \multicolumn{5}{c}{ Anova } \\
\hline $\begin{array}{c}\text { Source of } \\
\text { Variation }\end{array}$ & SS & DF & MS & F & P-value \\
\hline $\begin{array}{c}\text { Between } \\
\text { Groups } \\
\text { Within } \\
\text { Groups } \\
\text { Total }\end{array}$ & 124.57 & 1.00 & 124.57 & 21.09 & 0.00 \\
\hline
\end{tabular}

\section{Comparison of Base Pay versus Training}

Comparisons were run between the mean ratings for base pay versus training. Analysis of variance was used to test the comparisons. These results are shown in Table 14:

Table 14 indicates that base pay in has a positive relationship with IT sales professionals' decision to stay with the firm as compared with their respective employer.

Comparison of Career Advancement versus Bonus Plan

Comparisons were run between the mean ratings for bonus plan versus advancement. Analysis of variance was used to test the comparisons. These results are shown Table 15:

Table 15 shows that there were little difference between advancement and bonus plan in the decisions made by IT 
sales professionals to stay with their respective employer.

Table 15. Analysis of Variance: Career Advancement versus Bonus Plan Summary

\begin{tabular}{lccccc}
\hline \multicolumn{1}{c}{ Groups } & Count & Sum & Average & Variance \\
\hline \multicolumn{7}{c}{$\begin{array}{c}\text { Advancement } \\
\text { Bonus Plan }\end{array}$} & 116 & 833 & 7.18 & 8.13 \\
\hline \multicolumn{6}{c}{ Anova } \\
\hline $\begin{array}{l}\text { Source of } \\
\text { Variation }\end{array}$ & SS & DF & MS & F & P-value \\
\hline $\begin{array}{l}\text { Between } \\
\text { Groups }\end{array}$ & 1.90 & 1.00 & 1.90 & 0.22 & 0.64 \\
$\begin{array}{l}\text { Within } \\
\text { Groups } \\
\text { Total }\end{array}$ & 1963.99 & 230.00 & 8.54 & & \\
\hline
\end{tabular}

Comparison of Career Advancement versus Base Pay

Comparisons were run between the mean ratings for bonus plan versus advancement. Analysis of variance was used to test the comparisons. These results are shown in Table 16:

Table 16. Analysis of Variance: Career Advancement versus Base Pay Summary

\begin{tabular}{cccccc}
\hline Groups & Count & Sum & Average & Variance \\
\hline Base Pay & 116 & 905 & 7.80 & 6.21 \\
Advancement & 116 & 833 & 7.18 & 8.13 \\
\hline \multicolumn{6}{c}{ Anova } \\
\hline $\begin{array}{c}\text { Source of } \\
\text { Variation }\end{array}$ & SS & DF & MS & $\boldsymbol{F}$ & P-value \\
\hline Between Groups & 22.34 & 1.00 & 22.34 & 3.12 & 0.08 \\
Within Groups & 1649.64 & 230.00 & 7.17 & & \\
\hline
\end{tabular}

The analysis of variance indicates that there was little difference between the mean values of base pay and advancement. The determination factors that are related to the retention of IT sales professionals led to the formation of the directional and null hypotheses used in this research study. The independent variables that were compared in this research study were base pay, relationship with manager, training, career advancement, job fulfillment, and job satisfaction.

\section{Discussion}

The results from this study are very interesting. Retaining sales professionals is a challenge in most IT Solutions Organizations. The traditional view point was that salary based factors such as base pay, commissions and bonus plans were critical driving forces to motivate sales professionals to continue with their current employer. This research sheds light on this issue of determining salary versus non-salary factors in motivating sales professionals not to change their jobs. The findings of this study present a need for IT solutions companies to shift away from the transactional model of leadership practiced by the traditional high sales environment to a transformational style of leadership. Transformational leadership may be the optimal model for maximizing the retention of IT sales professionals based on the unique requirements of companies in the IT solutions in- dustry coupled with the higher degree of technical knowledge required by IT sales professionals compared to the traditional sales professional. Two important considerations can be drawn from the results of this study.

1. It is important to concentrate efforts on understanding the role that non-salary factors play in sale professionals' decision to continue their current employment

2. Equally important there is a need for a greater focus on both non-salary and salary factors to obtain an optimal solution to increasing retention and improving the performance of IT sales professionals.

\section{Conclusions}

The following recommendations are made to the IT Solutions Organizations based on the findings of this research study:

- Job satisfaction and sense of ownership have a stronger relationship on the retention of IT sales professionals than salary compensation.

o The implication of the above finding is that the optimal solution to increasing retention and improving the performance of IT sales professionals is to concentrate on sales professionals' job satisfaction and give attention to their sense of ownership.

- This research study revealed that other non-salary factors play an important role in IT sales professional retention. Job satisfaction and sense of ownership have a stronger relationship on the retention of IT sales professionals than salary compensation.

o This finding has implications for the need for sales managers to constantly take the pulse of the sales professionals' satisfaction. It is being recommended that sales managers should address sales professionals' job satisfaction on a regular basis not only just once a year.

- Sales managers should accompany sales professionals during visits with their customers. This helps sales managers have a better understanding sales professionals needs and their satisfaction with the company's products and services.

- The non-salary factors that are important are good scope for advancement, caring by the manager, job being very fulfilling and challenging and good training programs.

$\circ$ The implication for sales management is to care for their sales professionals and ensure that they have good scope for advancement.

o The other implication for sales management is to make sure the sales position is challenging and there are training programs to help sales professionals meet their goals.

- Sales support is important. Some of types of support needed by the sales professionals are engineering and design services for preparation of the proposal, timely review of sales proposal, clear pricing policies, good installation service, and excellent customer service after the installation.

- Sales Management has various implications from this finding. Sales management should make it a point to meet 
with various functions within the organizations with which sales professionals interact and interfaces on a regular bases to identify and evaluate customer needs and provide solutions to their customers. These functions typically are engineering, marketing, customer service as we as installation and repair departments as well as shipping departments.

\section{ACKNOWLEDGEMENTS}

We would like to thank all the IT sales professionals and sales managers that participated in this study. They provided valuable data and set the foundation for completing one of our most scholarly accomplishments. We encourage others to take a bold step in helping to make a positive change in society and business by investing in educational and research pursuits. We dedicate this work to those who believe that they can make a difference by providing opportunities to others who aspire to do great things in life and further the role of business and society. This research is especially important for the sales function which is vital to the success of any profit and nonprofit-oriented undertakings.

\section{REFERENCES}

[1] Addae, H.M., Parboteeah, K.P., \& Velinor, N. (2008). Role stressors and organizational commitment: public sector employment in St Lucia. International Journal of Manpower, 29(6), 567

[2] Allen, E. (2007). How to make your staff feel valued. Caterer \& Hotel Keeper. 197(4499), 50-51

[3] Barbour, T. (2007). Ten steps to better management: know your employees and know yourself. Alaska Business Monthly, 23(11), 28-32

[4] Bradford, K.D., Crant, J.M., \& Phillips, J.M. (2009). How suppliers affect trust with their customers: The role of salespersons job satisfaction and perceived customer importance. Journal of Marketing Theory and Practice, 17(4), 383-394

[5] Brandt, J.R. (2004). Vocal talents: Great leaders communicate their business' messages and then shut up and get out of the way. Inside Business, 6(8), 22-23. Retrieved May 20, 2011, from the Gale PowerSearch database

[6] Brooker, B. (2008). Getting them is tough; keeping them is tougher. Advertising Age, 79(2), 20

[7] Buckley, M.R., Carraher, S.M., Carraher, S.C., Ferris, G.R., \& Carraher, C.E. (2008). Human resource issues in global entrepreneurial high technology firms: Do they differ? Journal of Applied Management and Entrepreneurship 13(1), 4-14

[8] Bureau of Labor Statistics. (2009). Economic News Release

[9] Cross V., Hicks, C., Parle, J., \& Field, S. (2006). Perceptions of the learning environment in higher specialist training of doctors: implications for recruitment and retention. Medical Education, 40(2)121-128
[10] Day, A. (2007). Sales esteem. The American Salesman, 52(1), 3-8. Retrieved May 24, 2011, from the ProQuest database

[11] Demographics Now. (2009). Population Ranking

[12] Draper, A.K. (2004). The principles and application of qualitative research. The Proceedings of the Nutrition Society, 63(4), 641-646

[13] Ferguson, S. (2009). IT professionals see salary increase but job security remains top concern. eWeek.com

[14] Feyerherm, A., \& Vick, Y. (2005). Generation X women in high technology: Overcoming gender and generational challenges to succeed in the corporate environment. Career Development International, 10(3), 216-229

[15] Geare, A., Edgar, F., \& McAndrew, I. (2006). Employment relationships: Ideology and HRM practice. International

[16] Griffin, J. (2003). Twelve laws of loyalty. The Canadian manager, 28(2), 20

[17] Hayes, B.J. (2009). Six Sigma critical success factors. Six Sigma

[18] Hedden, C., \& Anselmo, J.C. 2008. Lessons learned. Aviation Week \& Space Technology, 171(8), 44-49

[19] Hoffman, T. (2008). Tried-and-true techniques. Computerworld, 42 (5), 36

[20] Ko, M., \& Osei-Bryson, K. (2008). Reexamining the impact of information technology investment on productivity using regression tree and multivariate adaptive regression splines (MARS). Information Technology and Management, 9(4), 285-299

[21] Langley, N. (2006). Certification is key to cash in on growth in IT security. (IDC survey). Computer Weekly

[22] Lee-Kelley, D.A., Blackman, J., \& Hurst, P. (2007). An exploration of the relationship between learning organisations and the retention of knowledge workers. The Learning Organization, 14(3), 204

[23] McShane, S.L., \& Von Glinow, M.A. (2003). Organizational behavior (2nd ed.). McGraw- Hill /Irwin

[24] Moderi, M., \& Foote, D. (2005). Are IT retention efforts working? Optimize, 4(12), 23-24

[25] Morgan, J., Campione, W., \& Jerrell, M. (2004). Wages and voluntary labor turnover: Comparing it workers with other professionals. Journal of Economics and Economic Education Research, 5(1), 99-126

[26] Pabilonia, S.W., \& Zoghi, C. (2005). Who gains from computer use? Impact on US wages. Perspectives on Labour and Income, 17(3), 27

[27] Prakash, D., \& Klotz, A. (2007). Should we discard the "qualitative" versus "quantitative" distinction? International Studies Review, 9(4), 753-754

[28] Puffer, S.M. (2004). Changing organizational structures: An interview with Rosabeth Moss Kanter. Academy of Management Executive, 18(2), 96-105

[29] Rexroad, C., \& Shoffner, D. (2003). Baby boomers and Generation Y: New audiences, new avenues. Practical Effect Corporate Communications 
[30] Samuels, M. (2005). Management - flexibility is the key to keeping parents in IT. How can IT employers do more to retain the skills of working parents? Computing, 26-31

[31] Schultz, B. (2007). Salary survey: IT pay falls short. Typical raises beat national rate of inflation, bringing average base pay to $\$ 86,700$. Yet network professionals aren't happy with their salary packages, our annual survey finds. Network World

[32] Sudheimer, E.E. (2009). Appreciating both sides of the generation gap: Baby boomer and generation $\mathrm{X}$ nurses working together. Nursing Forum, 44(1), 57-63

[33] Sutton, C. (2006). Get the Most Out of Six Sigma. Quality
45(3), 46-48

[34] Tae, H.L., Gerhart, B., Weller, I., \& Trevor, C.O. (2008). Understanding voluntary turnover: Path-specific job satisfaction effects and the importance of unsolicited job offers. Academy of Management Journal, 51(4), 651-671

[35] van Dyne, L., \& Pierce, J.L. (2004). Psychological ownership and feelings of possession: three field studies predicting employee attitudes and organizational citizenship behavior. Journal of Organizational Behavior, 25(4), 439-459

[36] Yost, D.S. (2006). Reflection and self-Efficacy: Enhancing the retention of qualified teachers from a teacher education perspective. Teacher Education Quarterly, 33(4), 59-76 